\title{
Recombinant adenovirus as a model to evaluate the efficiency of free chlorine disinfection in filtered water samples
}

\author{
Mariana A Nascimento, Maria E Magri, Camila D Schissi and Célia RM Barardi*
}

\begin{abstract}
Background: In Brazil, ordinance no. 2,914/2011 of the Ministry of Health requires the absence of total coliforms and Escherichia coli (E. coli) in treated water. However it is essential that water treatment is effective against all pathogens. Disinfection in Water Treatment Plants (WTP) is commonly performed with chlorine.

Methods: The recombinant adenovirus ( $\mathrm{rAdV}$ ), which expresses green fluorescent protein (GFP) when cultivated in HEK 293A cells, was chosen as a model to evaluate the efficiency of chlorine for human adenovirus (HAdV) inactivation in filtered water samples from two WTPs: Lagoa do Peri (pH 6.9) and Morro dos Quadros (pH 6.5). Buffered demand free (BDF) water (pH 6.9 and 8.0) was used as control. The samples were previously submitted to physicochemical characterization, and bacteriological analysis. Two free chlorine concentrations and two temperatures were assayed for all samples $\left(0.2 \mathrm{mg} / \mathrm{L}, 0.5 \mathrm{mg} / \mathrm{L}\right.$, and $15^{\circ} \mathrm{C}$, and $\left.20^{\circ} \mathrm{C}\right)$. Fluorescence microscopy (FM) was used to check viral infectivity in vitro and qPCR as a molecular method to determine viral genome copies. Real treated water samples from the WTP (at the output of WTP and the distribution network) were also evaluated for total coliforms, E. coli and HAdV.
\end{abstract}

Results: The time required to inactivate $4 \log _{10}$ of $\mathrm{rAdV}$ was less than $1 \mathrm{~min}$, when analyzed by FM, except for BDF pH 8.0 (up to $2.5 \mathrm{~min}$ for $4 \log _{10}$ ). The pH had a significant influence on the efficiency of disinfection. The qPCR assay was not able to provide information regarding rAdV inactivation. The data were modeled (Chick-Watson), and the observed Ct values were comparable with the values reported in the literature and smaller than the values recommended by the EPA. In the treated water samples, HAdV was detected in the distribution network of the WTP Morro dos Quadros (2.75 × $10^{3}$ PFU/L).

Conclusion: The Chick-Watson model proved to have adjusted well to the experimental conditions used, and it was possible to prove that the adenoviruses were rapidly inactivated in the surface water treated with chlorine and that the recombinant adenovirus expressing GFP is a good model for this evaluation.

Keywords: Recombinant GFP-adenovirus, Chlorine, Filtered water, Fluorescence microscopy, qPCR

\section{Background}

Currently, enteric viruses are considered to be the main etiological agents of waterborne diseases, accounting for $30-90 \%$ of gastroenteritis worldwide [1]. Enteric viruses are frequently aggregated in the environment [2], and due to the small size of the particles $(0.5-1.0 \mu \mathrm{m})$, they are not efficiently retained in the filtration stage at Water Treatment Plants (WTPs) [3]. Disinfection is

\footnotetext{
*Correspondence: celia.barardi@ufsc.br

Laboratório de Virologia Aplicada, Departamento de Microbiologia, Imunologia e Parasitologia, Universidade Federal de Santa Catarina, 88040-900 Florianópolis, Santa Catarina, Brazil
}

therefore critical for reducing the infectious virus concentrations in source water.

According to the guidance manual published in 1991 by the Environmental Protection Agency of the United States (US EPA), a $4 \log _{10}(99.99 \%)$ removal or inactivation of enteric viruses by filtration and/or disinfection is recommended. The EPA also recommends values for the contact time - $\mathrm{Ct}$ (disinfectant concentration $(\mathrm{mg} / \mathrm{L}) \mathrm{x}$ time $(\mathrm{min}))$ of 4,6 and 8 to achieve inactivation of $2 \log _{10}, 3 \log _{10}$ and $4 \log _{10}$, respectively, using free chlorine [4]. However, the values established in this manual were based on studies with hepatitis $\mathrm{A}$ in buffered demand free water at $5^{\circ} \mathrm{C}$. As 
the water quality can significantly affect the effectiveness of the disinfection by free chlorine [5], it is unclear whether these recommended $\mathrm{Ct}$ values are sufficient to inactivate other viral pathogens in different water matrices.

Enteric viruses are generally more resistant to environmental conditions and conventional water treatment using chlorination and filtration than enteropathogenic bacteria, and there is no potential for replication in the environment because the viruses are obligatory intracellular parasites. Although virus degradation is expected to occur, the amount of virus that remains is more meaningful than the amount of remaining bacteria that can re-grow after being excreted. There have been virus-related outbreaks with the consumption of water in compliance with bacterial standards [6].

The human adenovirus (HAdV) belongs to the Adenoviridae family, genus Mastadenovirus, comprising 57 serotypes [7]. HAdV has been indicated as a potential marker of human fecal contamination in water [6]. The current contaminant candidate list of the aquatic environment (CCL3) considers the adenovirus as a high priority emerging contaminant present in drinking water and a candidate contamination marker of the aquatic environment [8].

HAdV has been extensively detected in environmental matrices. In 2005, Choi and Jiang [9] found that $16 \%$ of the river samples in California, USA were positive for HAdV $\left(10^{2}-10^{4} \mathrm{gc} / \mathrm{L}\right)$. Albinana-Gimenez et al. in 2009 [10] described that $90 \%$ of the river water samples in Barcelona, Spain were HAdV positive $\left(10^{1}-10^{4} \mathrm{gc} / \mathrm{L}\right)$. Dong et al. in 2010 [11] detected HAdV in $100 \%$ of the sewage samples $\left(1.87 \times 10^{3}-4.6 \times 10^{6} \mathrm{gc} / \mathrm{L}\right)$ and in $83.33 \%$ of the recreational water samples $\left(1.7 \times 10^{1}-1.19 \times 10^{3}\right.$ $\mathrm{gc} / \mathrm{L}$ ) in New Zealand. Win-Jones et al., in 2011 [12] found that $60.6 \%$ of the European recreational and fresh water samples were positive for HAdV, with a mean value of $3.260 \times 10^{3} \mathrm{gc} / \mathrm{L}$. In 2012, Fongaro et al. [13] described an HAdV presence in $96 \%$ of the samples collected in the Peri Lagoon, Brazil $\left(1.73 \times 10^{6}-2.41 \times 10^{8} \mathrm{gc} / \mathrm{L}\right)$ and Garcia et al. (2012) [14] described a presence of HAdV in $100 \%$ of the river water samples in Brazil, with an average of $10^{7} \mathrm{gc} / \mathrm{L}$. In the same year, Ye et al. [15] described $100 \%$ HAdV positive for river and drinking water samples in Wuhan, China $\left(10^{2}-10^{4} \mathrm{gc} / \mathrm{L}\right)$.

Several studies have evaluated the inactivation efficiency of HAdV by free chlorine in buffer $[3,16,17]$ in waters from rivers and lakes [5], groundwater [3], seawater [18] and sewage [19]. However, the methods chosen to evaluate the HAdV infectivity are often time-consuming. The plaque assay has long been considered a standard method, although it can require 5 to 12 days to achieve results [5,17-19]. Other methods are based on genome detection, such as PCR or the observation of a cytopathic effect.
As an alternative, recombinant adenoviruses (rAdV) can be used as a viral model to study the water disinfection procedures. rAdV are defective in their replication, as they lack the early gene, E1, which is involved in viral gene transcription, DNA replication, and the inhibition of host cell apoptosis [20]. Thus, rAdV replication is weakened in this condition, unless the replication occurs in permissive cell lines that express the E1 gene products, such as the Human Embryonic Kidney (HEK) 293A cells [21]. rAdV replication can, therefore, be directly monitored by fluorescence methods, based on the expression of the green fluorescent protein (GFP) that is encoded by a gene incorporated into the viral DNA. HEK 293A cells infected with rAdV provide a novel reporter for viral infectivity assays, enabling the use of rapid $(24 \mathrm{~h})$ and quantitative methods of monitoring GFP expression in individual cells, such as fluorescence microscopy.

In this context, the goal of the present study was to evaluate the viral inactivation in water collected from two Water Treatment Plants after the filtration (nondisinfected) by subsequent free chlorine addition, using the recombinant adenovirus as a model. Buffered demand free (BDF) water was used as the control. This study also evaluates the treated water quality throughout the water distribution network in relation to the concentration of human adenovirus and total coliforms.

\section{Results}

Water quality of the Lagoa do Peri (LP) and Morro dos Quadros (MQ) water treatment plants

The physicochemical parameters of the source waters used in the disinfection experiments are shown in Table 1.

\section{Disinfection assays}

To determine the influence of the seeded virus stocks on the chlorine demand, the free chlorine decay was analyzed in the water samples with and without the seeding purified

Table 1 Physicochemical parameters of the water samples

\begin{tabular}{lll}
\hline & $\mathbf{L P}^{\mathbf{a}}$ & $\mathbf{M Q}^{\mathbf{b}}$ \\
\hline $\mathrm{pH}$ & 6.9 & 6.5 \\
Turbidity & $1.52 \mathrm{uT}$ & $0.7 \mathrm{uT}$ \\
Temperature & $25.3^{\circ} \mathrm{C}$ & $19.1^{\circ} \mathrm{C}$ \\
Conductance & $53 \mu \mathrm{S} / \mathrm{cm}$ & $24.1 \mu \mathrm{S} / \mathrm{cm}$ \\
Nitrite $\left(\mathrm{NO}_{2}^{-}\right)$ & $0.56 \mu \mathrm{g} / \mathrm{L}$ & $3.98 \mu \mathrm{g} / \mathrm{L}$ \\
Nitrate $\left(\mathrm{NO}_{3}^{-}\right)$ & $4.34 \mu \mathrm{g} / \mathrm{L}$ & $33.32 \mu \mathrm{g} / \mathrm{L}$ \\
Ammonia $\left(\mathrm{NH}_{3}^{+}\right)$ & $16.65 \mu \mathrm{g} / \mathrm{L}$ & $34.40 \mu \mathrm{g} / \mathrm{L}$ \\
Total coliforms & $>8.0 \mathrm{MPN} / 100 \mathrm{~mL}$ & $4.6 \mathrm{MPN} / 100 \mathrm{~mL}$ \\
E. coli & $>8.0 \mathrm{MPN} / 100 \mathrm{~mL}$ & $<1.1 \mathrm{MPN} / 100 \mathrm{~mL}$
\end{tabular}

a LP: Lagoa do Peri Water Treatment Plant.

${ }^{b}$ MQ: Morro dos Quadros Water Treatment Plant.

Samples harvested at the Lagoa do Peri (LP) and Morro dos Quadros (MQ) water Treatment Plants. 
virus stock. No significant differences were found between the two conditions $(\mathrm{P}>0.05)$ (not shown). In general, the concentrations remained constant during the analysis period, showing no significant decay $(P>0.05)$. The rates of the free chlorine decay, although very low, were used to model the exponential regression by the Chick-Watson model.

No significant log reduction of the viral stock was observed over time for all of the analyzed matrices $(\mathrm{P}>0.05)$ for the positive control (not shown). Thus, any $\log$ reduction observed in the experiments using the free chlorine was due to the germicidal efficacy of this compound and not to the exposure of the virus to the experimental conditions (e.g., time, matrix composition, and temperature).

The titer of the purified virus stock was $9 \times 10^{8} \mathrm{FFU} / \mathrm{mL}$, enough to observe a $4 \log _{10}$ reduction using fluorescence microscopy because the detection limit for this technique was $8.5 \times 10^{1} \mathrm{FFU} / \mathrm{mL}$ (the virus stock used to determine the detection limit had a titer of $8.5 \times 10^{7} \mathrm{FFU} / \mathrm{mL}$ ). Using this virus stock, the lowest ten-fold dilution that enabled us to count infected fluorescent cells was the $10^{-6}$ dilution and, for this reason, this dilution was considered the detection limit for this viral titer and for this amount of inocu$\operatorname{lum}\left(8.5 / 0.1 \mathrm{~mL}=8.5 \times 10^{1} \mathrm{FFU} / \mathrm{mL}\right)$. Figure 1 shows the fluorescent pattern of the HEK 293A cells infected with rAdV under fluorescence microscopy.

The free chlorine rAdV disinfection was performed in duplicate, with $0.2 \mathrm{mg} / \mathrm{L}$ and $0.5 \mathrm{mg} / \mathrm{L}$ free chlorine in the LP and MQ samples and in the BDF buffer $\mathrm{pH} 6.9$ and 8.0 , at $15^{\circ} \mathrm{C}$ and $20^{\circ} \mathrm{C}$. A four-log inactivation was attempted for all of the experiments. The time required to inactivate $4 \log _{10} \mathrm{rAdV}$ was less than $1 \mathrm{~min}$ for both concentrations $(0.2 \mathrm{mg} / \mathrm{L}$ and $0.5 \mathrm{mg} / \mathrm{L})$ of free chlorine when analyzed by fluorescence microscopy (Figures 2, 3 and 4), with the exception of the BDF buffer at $\mathrm{pH} 8.0$, which showed the slowest decay of approximately $2.5 \mathrm{~min}$ with $0.5 \mathrm{mg} / \mathrm{L}$ of free chlorine to decay $4 \log _{10}$ and $5 \mathrm{~min}$ with $0.2 \mathrm{mg} / \mathrm{L}$ of free chlorine to achieve the same decay (Figure 5).

The MQ water sample ( $\mathrm{pH}$ 6.5) showed the highest disinfection rate, requiring $7 \mathrm{~s}$ to reduce $4 \log _{10}$ with $0.5 \mathrm{mg} / \mathrm{L}$ and approximately $20 \mathrm{~s}$ with $0.2 \mathrm{mg} / \mathrm{L}$ at $20^{\circ} \mathrm{C}$ (Figure 4). In general, the viral inactivation was higher in MQ ( $\mathrm{pH}$ 6.5) (Figure 4), followed by LP ( $\mathrm{pH}$ 6.9), the BDF buffer $\mathrm{pH} 6.9$ (Figures 3 and 2) and finally the BDF buffer $\mathrm{pH} 8.0$ (Figure 5). When the influence of temperature was analyzed, no significant difference was found between the experiments performed at $20^{\circ} \mathrm{C}$ and $15^{\circ} \mathrm{C}(\mathrm{P}>0.05)$; therefore, only the results obtained at $20^{\circ} \mathrm{C}$
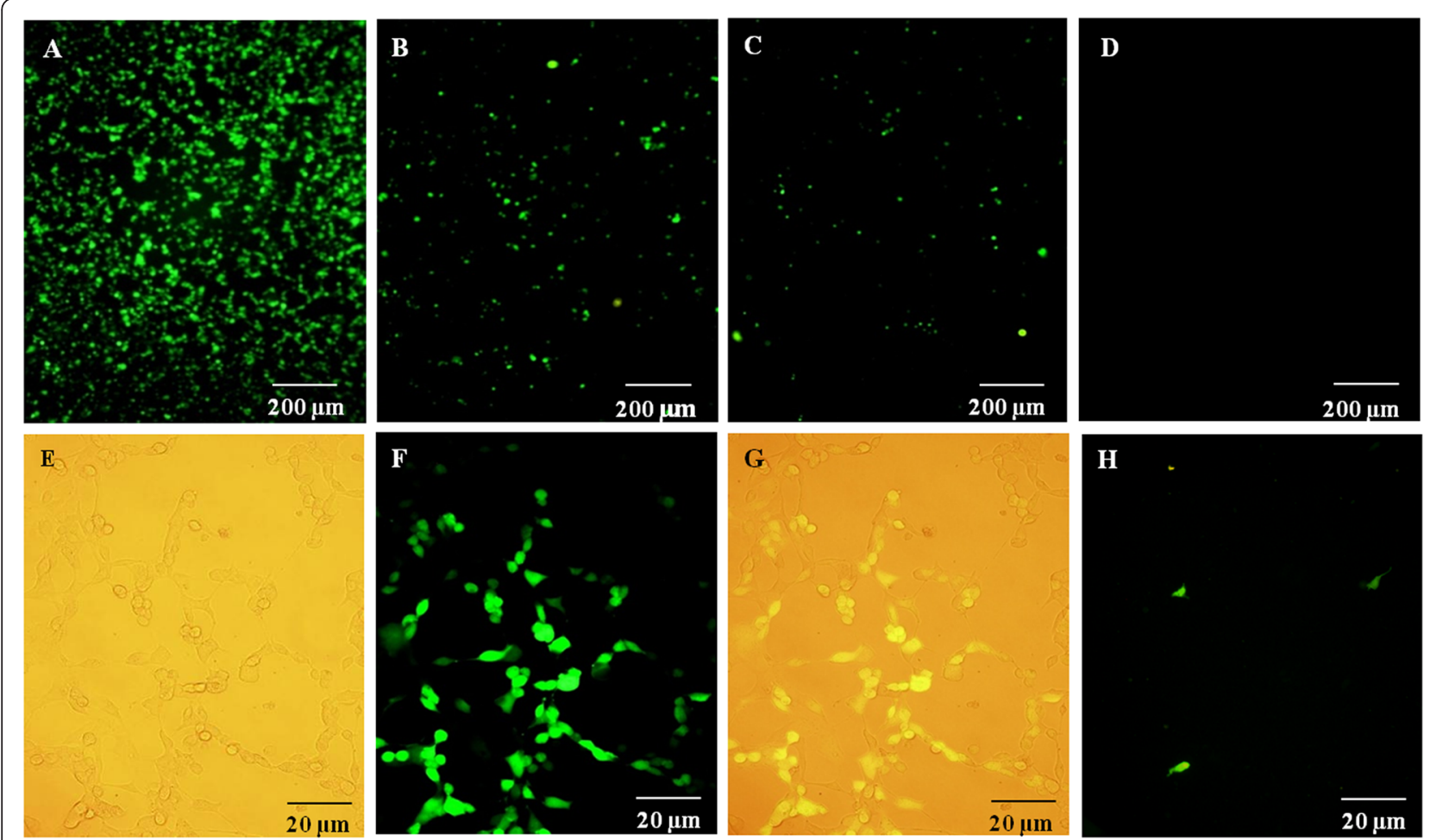

Figure 1 HEK 293A cells infected with rAdV by fluorescence microscopy and light microscopy. Viral concentration of $8.3 \times 10^{5} \mathrm{FFU} / \mathrm{mL}$ (A), $8.3 \times 10^{4} \mathrm{FFU} / \mathrm{mL}$ (B), $8.3 \times 10^{3} \mathrm{FFU} / \mathrm{mL}$ (C), and cell control (D) by fluorescence microscopy, 40x magnification. Cells infected with $8.2 \times 10^{5} \mathrm{FFU} / \mathrm{mL}$ by light microscopy $\mathbf{( E )}$, fluorescence microscopy $\mathbf{( F )}$ and merged $\mathbf{( G )}$, and an example of 3 green fluorescent cells considered to determine the viral titer (H), 400x magnification. 


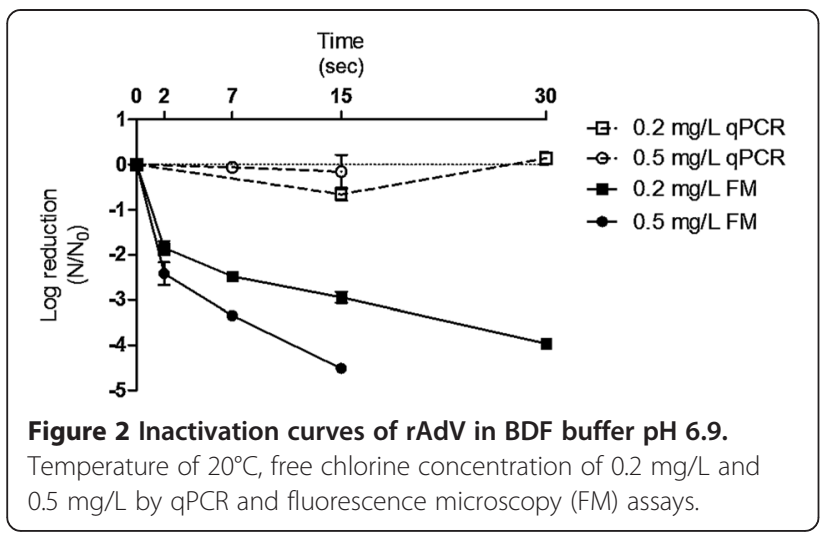

were expressed graphically. No significant variation of the logarithmic reduction was observed for all experimental conditions when analyzed by qPCR $(\mathrm{P}>0.05)$ (Figures 2, 3, 4 and 5).

No significant difference was found between LP and MQ when compared with the BDF buffer at $\mathrm{pH} 6.9$ $(\mathrm{P}>0.05)$. The experiments conducted with $10 \mathrm{~mL}$ and $40 \mathrm{~mL}$ also showed no significant difference $(\mathrm{P}>0.05)$.

\section{Kinetic modeling}

The Chick-Watson (CW) model was used to predict the free-chlorine inactivation kinetics of rAdV for each experimental condition. Table 2 lists the parameters estimated by the CW model analysis: $k^{\prime}$ (rate of free chlorine decay), $k$ (rate of viral inactivation) and $\mathrm{R}^{2}$ $\left(\operatorname{Ln}\left(\mathrm{N} / \mathrm{N}_{0}\right)\right.$ observed $\mathrm{x} \operatorname{Ln}\left(\mathrm{N} / \mathrm{N}_{0}\right)$ of the Chick-Watson model).

The $\mathrm{Ct}$ values $(\mathrm{mg} / \mathrm{L} \times \mathrm{min})$ predicted for the viral inactivation are shown in Table 3. As seen in Figures 2, 3, 4 and 5, the viral inactivation followed the same pattern, with lower $\mathrm{Ct}$ values of the $4 \log _{10}$ inactivation for MQ (0.067 and 0.101), followed by LP (0.14), the BDF buffer pH 6.9 (0.187) and finally the BDF buffer pH 8.0 (1.87 Ct value; Table 3).

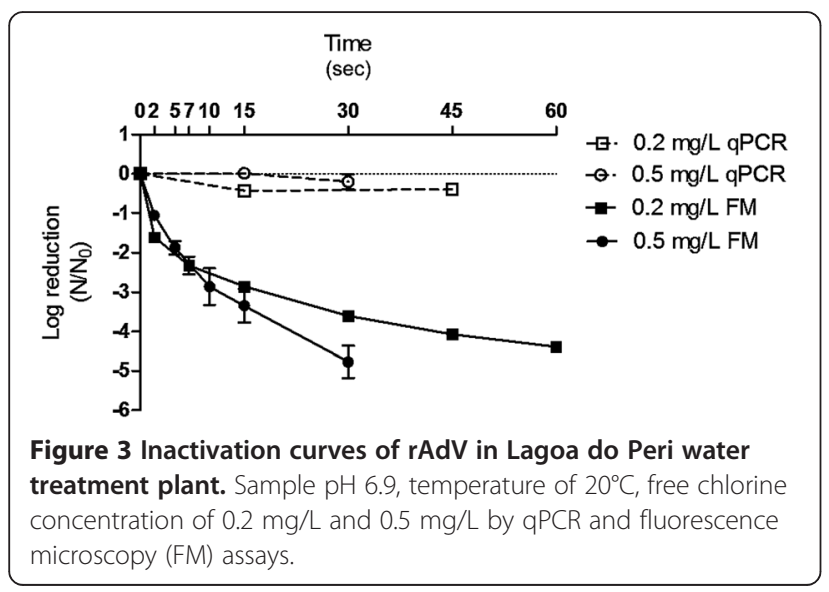

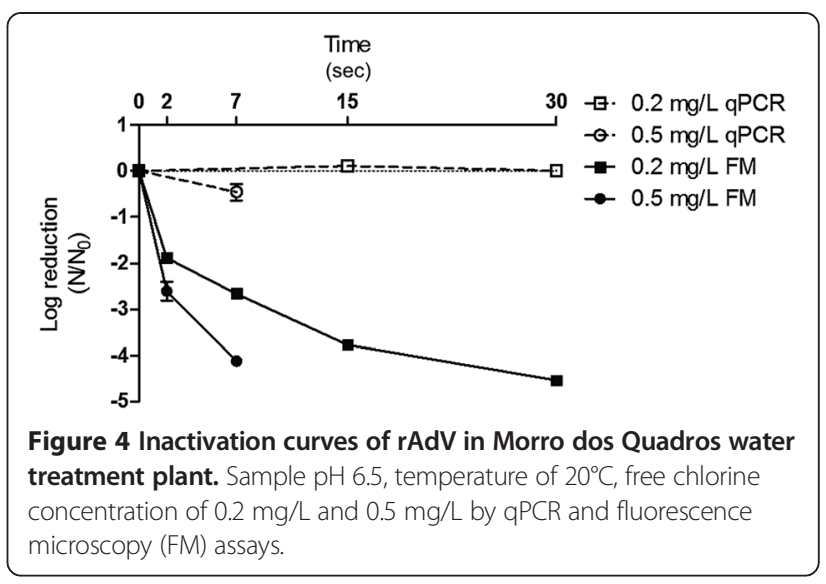

Treated water quality

The $\mathrm{t}-\mathrm{MQ}, \mathrm{t}-\mathrm{LP}, \mathrm{n}-\mathrm{MQ}$ and $\mathrm{n}-\mathrm{LP}$ water samples were analyzed for the total coliforms and Escherichia coli (E. coli), the free chlorine concentration $(\mathrm{mg} / \mathrm{L})$, and the HAdV viability. The average recovery of the organic flocculation for the virus concentration was $6.4 \%$. The range of the free chlorine concentration was from 0.57 to $4.0 \mathrm{mg} / \mathrm{L}$ and is within the standard required by the $\mathrm{MH}$ Ordinance 2.914/2011, which defines a minimum of $0.2 \mathrm{mg} / \mathrm{L}$ and a maximum of $5.0 \mathrm{mg} / \mathrm{L}$ [22]. None of the samples were positive for both the total coliforms and $E$. coli, with values lower than $1.1 \mathrm{MPN} / 100 \mathrm{~mL}$ (sensitivity limit). Among the tested samples, t-MQ showed contamination with $2.75 \times 10^{3} \mathrm{PFU} / \mathrm{L}$ infectious HAdV (value corrected by recovery), and at this point, the measured free chlorine concentration was $0.57 \mathrm{mg} / \mathrm{L}$. None of the other samples were positive for HAdV, with values lower than $1 \times 10^{3} \mathrm{PFU} / \mathrm{L}$ (sensitivity limit).

\section{Discussion}

The application of recombinant adenovirus provides a versatile system for therapeutic applications and gene expression studies, including gene transfer in vitro, gene therapy and vaccine therapy [20]. Despite this well-established use, we describe herein a novel application

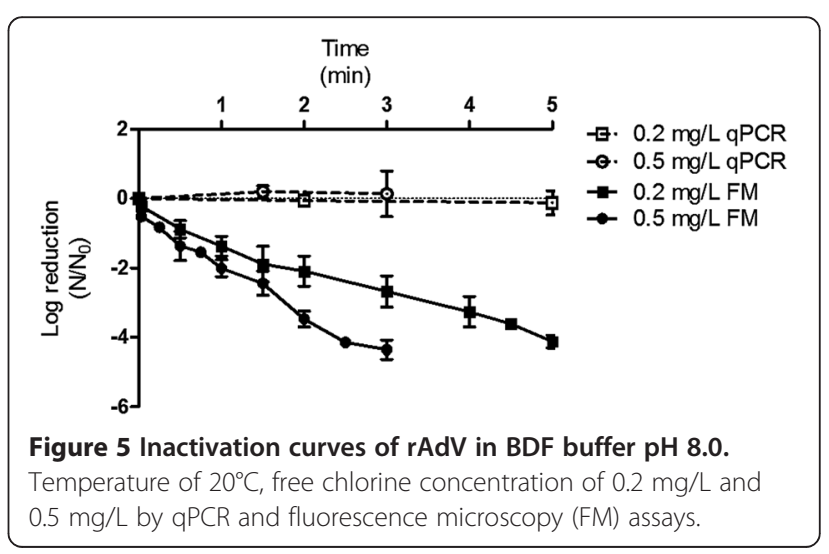


Table 2 Parameters estimated by Chick-Watson model analysis

\begin{tabular}{|c|c|c|c|c|}
\hline Water sample $^{\mathrm{a}}$ & Free chlorine $(\mathrm{mg} / \mathrm{L})$ & $k^{\prime}\left(\min ^{-1}\right)$ & $\mathrm{k}\left(\min ^{-1}\right)$ & $R^{2}$ \\
\hline \multirow[t]{2}{*}{$\mathrm{BDF} \mathrm{pH} 8.020^{\circ} \mathrm{C}$} & 0.2 & 0.0001 & 3.6645 & 0.9709 \\
\hline & 0.5 & 0.0001 & 6.1967 & 0.9719 \\
\hline \multirow[t]{2}{*}{ BDF pH $6.920^{\circ} \mathrm{C}$} & 0.2 & 0.0001 & 35.9078 & 0.7348 \\
\hline & 0.5 & 0.0001 & 82.9889 & 0.8125 \\
\hline \multirow[t]{2}{*}{ LP $20^{\circ} \mathrm{C}$} & 0.2 & 0.105 & 52.0292 & 0.7852 \\
\hline & 0.5 & 0.397 & 47.5822 & 0.9106 \\
\hline \multirow[t]{2}{*}{ LP $15^{\circ} \mathrm{C}$} & 0.2 & 0.105 & 72.7319 & 0.8382 \\
\hline & 0.5 & 0.397 & 44.3554 & 0.7655 \\
\hline \multirow[t]{2}{*}{$\mathrm{MQ} 20^{\circ} \mathrm{C}$} & 0.2 & 0.147 & 100.5580 & 0.7913 \\
\hline & 0.5 & 0.0001 & 162.8456 & 0.8712 \\
\hline \multirow[t]{2}{*}{$\mathrm{MQ} 15^{\circ} \mathrm{C}$} & 0.2 & 0.147 & 88.9608 & 0.7844 \\
\hline & 0.5 & 0.0001 & 75.0303 & 0.769 \\
\hline
\end{tabular}

aBDF: Buffered demand free; LP: Lagoa do Peri Water Treatment Plant; MQ: Morro dos Quadros Water Treatment Plant.

Values of $k$ '(rate of decay of free chlorine), $k$ (rate of viral inactivation) and $\mathrm{R}^{2}$ ( $\mathrm{Ln}(\mathrm{N} / \mathrm{N} 0)$ observed $x \mathrm{Ln}$ (N/NO) of Chick-Watson model determined for each experimental condition.

of rAdV in the environmental virology field, especially in disinfection assessment studies. The current study shows, for the first time, the efficiency of free chlorine disinfection of rAdV in water samples undergoing treatment for human consumption. The temperatures of $15^{\circ} \mathrm{C}$ and $20^{\circ} \mathrm{C}$ mimic the temperature range of the natural waters in south Brazil during the winter and summer seasons [23], respectively, and the $\mathrm{pH}$ conditions, which were not modified. We believe that it is very important to select temperatures that assess the real conditions that occur in the real environment. Comparison techniques based on genome detection (qPCR) and infectivity (cell culture) are also important because risk assessment studies based on genomic copy detection are encouraged [24-28], and other studies have reported that free chlorine can damage genetic material $[29,30]$.

The use of rAdV proved to be economical, convenient and fast for several reasons: it does not require the use of primary and secondary antibodies; it decreases the possibility of overestimating the viral titers due to non-specific binding; it avoids cell loss during the washing stages commonly performed in immunodetection techniques; and it is faster $(24 \mathrm{~h})$ than the conventional plaque assay method ( 7 to 10 days), described by Cromeans et al. (2008) [31].

Regarding the GFP fluorescence stability in chlorine solutions, according to Mazzola et al. (2006) [32], who evaluated the GFP stability in chlorinated water and buffered solutions, the main conclusion was that GFP is a suitable fluorescent marker for monitoring disinfection effectiveness. They observed that, with constantly stirred solutions, the GFP fluorescence decreased abruptly after
Table 3 Ct values for rAdV inactivation by free chlorine determined by Chick-Watson model

\begin{tabular}{|c|c|c|c|}
\hline $\begin{array}{l}\text { Water } \\
\text { sample }^{a}\end{array}$ & $\begin{array}{l}-\log _{10} \\
\text { inactivation }\end{array}$ & $\begin{array}{l}\mathrm{Ct}(\mathrm{mg} / \mathrm{L} \times \mathrm{min}) \text { model } \\
\text { (mean/standard deviation) }\end{array}$ & $\begin{array}{l}\text { EPA guidance } \\
\text { manual Ct } \\
\text { value (1991) }\end{array}$ \\
\hline \multirow{3}{*}{$\begin{array}{l}\text { BDF pH } \\
8.020^{\circ} \mathrm{C}\end{array}$} & 2 & $0.87 / 0.17$ & 1 \\
\hline & 3 & $1.49 / 0.70$ & 2 \\
\hline & 4 & $1.87 / 0.88$ & 3 \\
\hline \multirow{3}{*}{$\begin{array}{l}\text { BDF pH } \\
6.920^{\circ} \mathrm{C}\end{array}$} & 2 & $0.016 / \mathrm{NO}^{\mathrm{b}}$ & 1 \\
\hline & 3 & $0.091 / 0.047$ & 2 \\
\hline & 4 & $0.187 / 0.08$ & 3 \\
\hline \multirow[t]{3}{*}{ LP $20^{\circ} \mathrm{C}$} & 2 & $0.022 / 0.005$ & 1 \\
\hline & 3 & $0.06 / 0.028$ & 2 \\
\hline & 4 & $0.14 / 0.028$ & 3 \\
\hline \multirow[t]{3}{*}{ LP $15^{\circ} \mathrm{C}$} & 2 & $0.014 / 0.005$ & 2 \\
\hline & 3 & $0.06 / 0.028$ & 3 \\
\hline & 4 & $0.14 / 0.028$ & 4 \\
\hline \multirow[t]{3}{*}{ MQ $20^{\circ} \mathrm{C}$} & 2 & $0.005 / \mathrm{NO}^{\mathrm{b}}$ & 1 \\
\hline & 3 & $0.027 / 0.015$ & 2 \\
\hline & 4 & $0.067 / 0.013$ & 3 \\
\hline \multirow[t]{3}{*}{$\mathrm{MQ} 15^{\circ} \mathrm{C}$} & 2 & $0.017 / 0.001$ & 2 \\
\hline & 3 & $0.048 / 0.013$ & 3 \\
\hline & 4 & $0.101 / 0.033$ & 4 \\
\hline
\end{tabular}

aDF: Buffered demand free; LP: Lagoa do Peri Water Treatment Plant; MQ Morro dos Quadros Water Treatment Plant.

bNO: not observed.

$\mathrm{Ct}$ values (mean/standard deviation) calculated for each experimental condition and compared with EPA Guidance Manual.

contact with chlorine in concentrations greater than $150 \mathrm{ppm}$, and the GFP fluorescence intensity was reduced by $42 \%$ in the initial $30 \mathrm{~s}$ of contact with a $70 \mathrm{ppm}$ phosphate buffered chlorinated solution. Webb et al. (2001) [33] exposed Aureobasidium pullulans cells expressing GFP to chlorinated solutions (25-150 ppm) and observed that the loss of GFP fluorescence was highly correlated with a decrease of the number of viable cells. Casey and Nguyen (1995) [34] exposed Escherichia coli cells also expressing GFP and observed the same result as Webb et al. (2001). In the present study, the chlorine concentrations employed were $0.2 \mathrm{ppm}$ and $0.5 \mathrm{ppm}$, much lower than the values described above. Therefore, we can conclude that the GFP fluorescence itself was not affected by this low concentration of applied chlorine, and the lack of fluorescence is certainly due to a lack of rAdV replication. This phenomenon was also proven by the same effect of the chlorine on viral disinfection using non-recombinant human adenovirus, which was previously described in the literature $[3,5,17]$.

Viral purification is essential for the experiments of disinfection by free chlorine because viral suspensions contain considerable amounts of organic matter that consumes free chlorine, preventing its virucidal and bactericidal 
action [18]. This work was the first to use chromatography as a method of purification and proved to be comparable to studies using other forms of purification, with comparable and adequate $\mathrm{Ct}$ values $[5,17]$ because the concentrations of disinfectant did not vary significantly in the presence of the purified virus stock $(\mathrm{P}>0.05)$.

No significant difference in the disinfection efficiency was observed $(\mathrm{P}>0.05)$ between the tested temperatures $\left(15^{\circ} \mathrm{C}\right.$ and $\left.20^{\circ} \mathrm{C}\right)$. However, the $\mathrm{pH}$ variation exerted a great influence on the disinfection efficiency: the $\mathrm{Ct}$ for the $4 \log _{10}$ disinfection at BDF pH 8.0 (1.87) was 10 times greater than the $\mathrm{Ct}$ at $\mathrm{BDF} \mathrm{pH} 6.9$ (0.187). This result is due to residual free chlorine in both $\mathrm{pHs}$; at $\mathrm{pH} 8.0$ there is approximately $25 \% \mathrm{HOCl}$ and $75 \%$ of the hypochlorite ion $\left(\mathrm{HCl}^{+}\right)$, and at $\mathrm{pH} 6.9$, approximately $80 \%$ is $\mathrm{HOCl}$, and $20 \%$ is $\mathrm{HCl}^{+}$. According to AWWA (2006) [35], the germicidal efficiency of $\mathrm{HOCl}$ is approximately 100 times greater than $\mathrm{HCl}^{+}$, which explains the observed results; therefore, the $\mathrm{pH}$ of the water can cause a variability in the disinfection efficiency.

Nevertheless, fresh water submitted to water treatment is constantly influenced by geological features. It is well known that the levels of chemicals in soils reflect the levels at the source rock, except in cases with anthropogenic influence [36,37], and the geology has a great influence on the chemical characteristics of the soil and surface water [38]. Moreover, it has been demonstrated that the $\mathrm{pH}$ values can vary in different water bodies, such as rivers, water reservoirs or estuaries, depending on the season [39-41] and the daily basis $[40,42]$ and spatially (variation throughout the water layer or sampling sites) $[42,43]$. Furthermore, air pollutants, such as carbon dioxide $\left(\mathrm{CO}_{2}\right)$, have a great influence on the $\mathrm{pH}$ of water because air pollutants can enter the water through biological metabolism involving organic carbon and through equilibrium with the atmosphere. Once in the water, $\mathrm{CO}_{2}$ reacts and forms bicarbonate $\left(\mathrm{HCO}_{3}^{-}\right)$and carbonate $\left(\mathrm{CO}_{3}^{2-}\right)$, decreasing the $\mathrm{pH}$. Therefore, more air pollution results in more $\mathrm{CO}_{2}$ in the water and higher water acidity [44]. Some other factors can affect the disinfection efficiency, such as antioxidants from commercial hygiene products, which reduce hypochlorite to chloride ions and decrease the free chlorine available for disinfection $[45,46]$. In addition, it is well known that the temperature range can influence the $\mathrm{pH}$, as well as the $\mathrm{CO}_{2}$ solubility and may vary on a daily basis [47]. Altogether, these factors can affect the $\mathrm{pH}$ and change the disinfection dynamics. Thus, it is essential to carefully control the $\mathrm{pH}$ in water treatment plants throughout the process, especially before the addition of chlorine, due to its great influence on the disinfection performance.

It is possible to observe that the inactivation curves for all of the experimental conditions, except for the BDF $\mathrm{pH}$ 8.0, were characterized by two phases: an initial phase in which the inactivation occurred rapidly (approximately $2 \log _{10}$ in 2 seconds), followed by a phase with a lower rate of inactivation, which may be designated the "tailing phase." Page et al. (2009) [16] described that the loss of disinfection efficiency observed during the tailing phase is most likely due to the rapid change of specific chemical moieties on the viral structure that preferentially react with $\mathrm{HOCl}$. Thus, some authors propose that the $\mathrm{HOCl}$-mediated transformation of proteins, which is due to the high reactivity with proteins and their abundance in biological systems, plays a key role in the loss of the biological function of this form of the free residual chlorine, leading to the formation of the tailing phase [48]. As the main feature, adenovirus capsids are composed of proteins (fibers, pentons and hexons) that are physically exposed to the disinfectant. These proteins contain functional groups, such as amines and thiols, that react with free chlorine, leading to a loss of the biological function of the disinfectant [49].

The inactivation curve in the BDF $\mathrm{pH} 8.0$ experiments may be associated with damage involving secondary oxidizing agents [16]. In addition, at this $\mathrm{pH}$, the $\mathrm{HOCl}$ concentration is approximately 25\% [35], making the disinfection slower with no biphasic behavior observed.

The qPCR assay has already proven to be fast and specific for the detection and quantification of rAdV genomes. However, this technique does not provide sufficient information about inactivated viruses compared with the fluorescence microscopy technique after cell culture. The time necessary for the assays was determined by the disinfection achievement. Therefore, once the $4 \log _{10}$ of disinfection was achieved, the experiment was considered concluded, although the viral genomic copies did not show a significant log reduction. In fact, some studies had performed viral disinfection studies employing PCR, and some studies indeed showed a reduction of the viral copies. Nevertheless, they observed the same profile: the genome integrity decreased more slowly than the viral viability [18,19,30,50-54]. Although some studies have reported that free chlorine can damage the viral genetic material [30] by interacting with the amine group of nucleotides [29], it is suggested that the extent of DNA damage caused by free chlorine is not sufficient to detect viral inactivation by the qPCR technique, which often results in very small amplicons [55]. Even with qualitative PCR using primer sets that generate greater amplicons (400 bp to 1,215 bp), the genome integrity is not correlated with the viability of HAdV because the PCR products are generated even when higher concentrations of chlorine are used [30]. This result suggests that the ability of free chlorine to cause damage in the viral genome is limited [30], and viruses with lesions in the capsid proteins caused by chlorine may still contain their genomes that are protected from the inactivation procedures. Thus, the viral nucleic acids detected by PCR or qPCR can be derived 
from infective and non-infective damaged viruses and from free nucleic acids from lysed viruses, and the results obtained by cell culture, when possible, are more representative of the actual health risk. Therefore, risk assessment studies based on genomic copy detection are inadequate, overestimating the actual risk of consuming drinking water treated with chlorine.

The absence of viable HAdV in the output of both WTPs and the presence of infectious virus in the distribution network suggest that the water treatment is efficient for the inactivation of HAdV; however, the water is recontaminated during its distribution and/or storage. Thus, low concentrations of residual free chlorine throughout the water distribution system are not sufficient to inactivate high viral loads that are accidentally re-introduced after the water treatment process [3].

It is postulated that biofilms in the drinking water distribution networks may play a role in the accumulation, protection and dissemination of pathogens [56]. The formation of biofilms has been described to provide bacteria much greater resistance to free chlorine, and it has also been shown that viruses can adsorb into biofilms [57]. The detection of viable HAdV in the distribution network may be due to viral aggregation and adsorption by particles, which have previously been reported as increasing the resistance to chlorine and the environment $[2,3]$ or adsorption into biofilms, also protecting them from the action of the free chlorine disinfectant.

As described in the literature, the human adenovirus is rapidly inactivated by free chlorine. However, it is difficult to make a direct comparison of the $\mathrm{Ct}$ values due to variations in the experimental conditions, especially the technique used for the viral purification [5]. Thurston-Enriquez et al. (2003) [3], Kahler et al. (2010) [5], and Cromeans et al. (2010) [17] reported Ct values similar to those observed in the present study, except for BDF at $\mathrm{pH} 8.0$, which was reported previously as 0.24 to inactivate $4 \log _{10}$ [3], in contrast to the 1.87 value observed in this study. However, the $\mathrm{Ct}$ value of 0.24 that was described by Thurston-Enriquez et al. (2003) [3] was calculated by the model, whereas the $\mathrm{Ct}$ observed in the experiment (not modeled) was 36.09 for the $4 \log _{10}$ reduction. Taken together, these data indicate the high susceptibility of the human adenovirus to free chlorine. Because the present work employed $\mathrm{rAdV}$, and the $\mathrm{Ct}$ values reported in the literature for HAdV are comparable, this result confirms the applicability of rAdV as a model for HAdV for studies of free chlorine disinfection and discards the need to perform all experiments with HAdV in parallel in this study. By comparing the $\mathrm{Ct}$ values recommended by the EPA [4] with those predicted by modeling, the values are lower than those recommended in all of the experimental conditions, providing a margin of safety for free chlorine water treatment in terms of the human adenovirus.
The Chick-Watson model was chosen as it best fits the reactors in the batch mode or ideal piston, in which the longitudinal dispersion is equal to zero [58]. As the experiments were performed in 10 or $40 \mathrm{~mL}$, the longitudinal dispersion is disregarded. The values of $k$ (inactivation constant rate) calculated by the Chick-Watson model are in agreement with what was observed: the inactivation was faster in MQ, followed by LP/BDF pH 6.9 and finally BDF pH 8.0 (Table 2 and Figures 2, 3, 4 and 5) because the $k$ value is directly proportional to the inactivation rate.

The constants of the Chick-Watson model described herein $\left(k, k^{\prime}\right)$ were determined by conducting bench experiments. These constants are considered characteristic for the rAdV inactivation kinetics, the specific conditions of the $\mathrm{pH}$ and temperature, and the composition of the environmental matrices. Therefore, these constants can be used to calculate the $\mathrm{Ct}$ at other chlorine concentrations, without the need to perform additional bench experiments.

\section{Conclusion}

The concentrations of chlorine $(0.2 \mathrm{mg} / \mathrm{L}$ and $0.5 \mathrm{mg} / \mathrm{L})$ applied to the filtered surface water were effective in inactivating the recombinant adenovirus, which proved to be highly susceptible to chlorine under the conditions studied. The factor that most influenced the disinfection was the $\mathrm{pH}$. The rAdV proved to be a suitable model for this assessment, comparable to the results described in the literature in relation to the non-recombinant human adenovirus. Additionally, the matrix composition did not seem to interfere with the disinfection efficiency. The detection of viable HAdV in the supply network suggests a re-contamination of the water, and the residual chlorine concentration may not be sufficient to inactivate the viruses that have been introduced after the water treatment process.

\section{Materials and methods \\ Virus and cell line}

The recombinant human adenovirus (rAdV) serotype 5 was propagated in HEK 293A cells, which were maintained in growth medium composed of Dulbecco's Modified Eagle Medium (DMEM 1X), supplemented with 10\% of fetal bovine serum (FBS) and 1\% of HEPES. Five hundred milliliters of the virus stock was produced by a host cell infection using a multiplicity of infection (MOI) of 5. After $24 \mathrm{~h}$ of incubation, the flasks were freeze-thawed three times and centrifuged at 3,500 $\times \mathrm{g}$ for $15 \mathrm{~min}$. The supernatant was recovered and submitted to viral purification using the Vivapure ${ }^{\bullet}$ AdenoPack Stedin Sartorius $^{\text {Tat }} 500$ commercial kit.

Briefly, $500 \mathrm{~mL}$ of the infected cell supernatant was treated with $12.5 \mathrm{U}_{\mathrm{mL}}^{-1}$ of Benzonase ${ }^{\circ}$ for $30 \mathrm{~min}$ at $37^{\circ} \mathrm{C}$, with the aim of degrading the nucleic acids from 
the cells and the viral particles. After adding Loading Buffer $^{\mathrm{Tm}}$, this suspension was pumped at $10 \mathrm{~mL} / \mathrm{min}$ through the chromatography filter and, based on the specific surface viral characteristics, the virus particles were specifically retained. The Washing Buffer ${ }^{\mathrm{Tm}}$ was then used to remove the contaminants, and $10 \mathrm{~mL}$ of the Elution Buffer ${ }^{\text {Tw }}$ at $1 \mathrm{~mL} / \mathrm{min}$ was used to elute the viruses from the filter. The eluate was reconcentrated by Vivaspin 20 by centrifugation at $6,000 \times \mathrm{g}$ for $15 \mathrm{~min}$, or until the virus stock could be concentrated at approximately $1 \mathrm{~mL}$. With the addition of $9 \mathrm{~mL}$ of phosphatebuffered saline (PBS), the purified virus stock was stored at $-80^{\circ} \mathrm{C}$ in aliquots of $0.1 \mathrm{~mL}$.

The human adenovirus 2 (HAdV2) was propagated in a continuous line of A549 cells (permissive cells derived from human lung carcinoma cells, European Collection of Cell Cultures). These cells were kindly donated by Dr. Rosina Gironès from the University of Barcelona, Spain. The A549 cells were propagated in growth medium, consisting of Dulbecco's Modified Eagle Medium high glucose (DMEM $\uparrow \mathrm{G} 1 \mathrm{X}$ ), supplemented with $5 \%$ of fetal bovine serum (FBS) and $1 \mathrm{mM}$ of sodium pyruvate.

\section{Treated water quality - collection and concentration}

These samples were collected to evaluate the quality of the treated water in relation to the HAdV viability, the total coliforms and the E. coli. For this evaluation, $4 \mathrm{~L}$ of treated water was collected from the Lagoa do Peri (WTP LP) and Morro dos Quadros (WTP MQ) Water Treatment Plants, henceforth referred to as the "treated LP" (t-LP) and "treated MQ" ( $\mathrm{t}-\mathrm{MQ})$, respectively. Another $4 \mathrm{~L}$ water samples were collected from one point in each of the two distribution network supplied by its respective WTP. The samples from the distribution network were collected from a tap at the Universidade Federal de Santa Catarina that was supplied by the WTP MQ and from a residence supplied by the WTP LP, here designated as "network LP" (n-LP) and "network MQ" (n-MQ). All four of the samples were previously treated with $10 \%$ sodium thiosulfate and submitted to an analysis of the total coliforms and E. coli and then subjected to the flocculation method for virus concentration, as described by Calgua et al. 2013 [59].

The samples were placed in 2 liter-glass beakers $(2$ beakers per sample), $1.5 \mathrm{~g} / \mathrm{L}$ of sea salts (SeaSalts Sigma) were added, and the $\mathrm{pH}$ was adjusted to 3.5 with a $1 \mathrm{~N} \mathrm{HCl}$ solution. A suspension of HAdV $\left(1 \times 10^{7} \mathrm{PFU}\right)$ was added to one of the beakers to assess the viral recovery. Twenty milliliters of skimmed milk solution at $\mathrm{pH} 3.5$ (Pre-flocculated Skimmed Milk, 0.1\% - Difco) prepared in artificial seawater (1.5 g/L SeaSalts - Sigma) was added to each beaker. Over a period of $8 \mathrm{~h}$ of stirring, the flocks of the acid milk provide a proper surface for viral adsorption and, after $8 \mathrm{~h}$ of resting these flocks settle.
The supernatant was aspirated, the precipitate was centrifuged at $7000 \times \mathrm{g}$ for $30 \mathrm{~min}$ at $4^{\circ} \mathrm{C}$, and the pellet was resuspended in $10 \mathrm{~mL}$ of phosphate buffer $\left(\mathrm{NaH}_{2} \mathrm{PO}_{4}\right.$, $\mathrm{Na}_{2} \mathrm{HPO}_{4}, 0.2 \mathrm{M}, 1: 2 \mathrm{v} / \mathrm{v}, \mathrm{pH}$ 7.5). The final concentrate was immediately submitted to the plaque assay.

\section{Plaque assay}

The $\mathrm{t}-\mathrm{LP}, \mathrm{t}-\mathrm{MQ}, \mathrm{n}-\mathrm{LP}$ and $\mathrm{n}-\mathrm{MQ}$ concentrated samples were treated with $1 \%$ PSA and inoculated in triplicate in a non-cytotoxic dilution in A549 cells for the plaque assay, as described by Cromeans et al. 2008 [31], with minor modifications (using 0.6\% Bacto-agar). Afterwards, the cells were stained with $20 \%$ Gram's crystal violet, the plaques were counted, and the results were expressed in Plaque Forming Units per liter (PFU/L). The theoretical limit of sensitivity limit of this method is $1 \times 10^{3} \mathrm{PFU} / \mathrm{L}$.

\section{Disinfection assays}

\section{Tested waters}

Water samples undergoing treatment were obtained at the Lagoa do Peri Water Treatment Plant (LP) located at Peri Lagoon, city of Florianópolis and the Morro dos Quadros Water Treatment Plant (MQ), located in Palhoça city. Both cities are located in Southern Brazil in the State of Santa Catarina. The water samples were collected after regular treatment (a filtration step) and immediately prior to chemical disinfection. Ten liters of each sample was collected, aliquoted in $500 \mathrm{~mL}$, and stored at $-20^{\circ} \mathrm{C}$.

Experiments were also conducted with buffered demand free (BDF) water, prepared by dissolving $0.54 \mathrm{~g}$ of $\mathrm{Na}_{2} \mathrm{HPO}_{4}$ (anhydrous) and $0.88 \mathrm{~g}$ of $\mathrm{KH}_{2} \mathrm{PO}_{4}$ (anhydrous) per liter of deionized, chlorine demand-free water. The $\mathrm{pH}$ was adjusted to 8.0 and 6.9 by adding $1 \mathrm{M} \mathrm{KH}_{2} \mathrm{PO}_{4}$. The BDF water was stored in chlorine-demand-free bottles at $4^{\circ} \mathrm{C}$ until use.

\section{Physicochemical parameters and fecal contamination analysis}

Using a multiparameter probe (YSI-85), the LP and MQ samples were submitted to physicochemical analysis in situ to determine the temperature, conductivity, and $\mathrm{pH}$. In the laboratory, the samples were analyzed for turbidity, nitrite $\left(\mathrm{NO}_{2}^{-}\right)$[60], nitrate $\left(\mathrm{NO}_{3}^{-}\right)$[61], and ammonia $\left(\mathrm{NH}_{3}\right)$ [62]. The nutrients were measured in the filtered water samples using a Millipore AP40-47 mm glass fiber.

A fecal contamination analysis was performed using a commercial Aquatest Coli - ONPG MUG Laborclin. One hundred milliliters of the MQ, LP, t-LP, t-MQ, n-LP and $\mathrm{n}-\mathrm{MQ}$ samples was analyzed, aliquoted in 5 tubes of $20 \mathrm{~mL}$ and incubated for $24 \mathrm{~h}$ at $35 \pm 2{ }^{\circ} \mathrm{C}$. The number of positive tubes was counted, and the results were expressed as the Most Probable Number (MPN) of total coliforms per $100 \mathrm{~mL}$. The sensitivity limit of this technique is $1.1 \mathrm{MPN} / 100 \mathrm{~mL}$. 


\section{Reagents and glassware treatments}

The glassware was made chlorine demand-free, as previously described [3]. The beakers were soaked overnight in a solution of $100 \mathrm{mg} / \mathrm{L}$ free chlorine, rinsed with chlorine demand free water and baked for $2 \mathrm{~h}$ at $200^{\circ} \mathrm{C}$. Following this initial treatment, only a soaking in free chlorine and rinsing in the demand free water were performed. For all of the disinfection experiments, a $2.5 \%$ sodium hypochlorite solution (2.38 $\mathrm{g} / \mathrm{L}$ of free chlorine) was used, which is suitable for the disinfection and treatment of drinking water, in accordance with the Brazilian regulations (Ministry of Health 3.1862.0001 MS). A chlorine stock solution of $100 \mathrm{mg} / \mathrm{L}$ was prepared, and a dilution in the $\mathrm{BDF}$ of this stock solution was performed to achieve the initial concentration of free chlorine to be used in the disinfection experiments $(0.2 \mathrm{mg} / \mathrm{L}$ and $0.5 \mathrm{mg} / \mathrm{L})$.

\section{Experimental design for disinfection}

The viral inactivation was performed with $0.2 \mathrm{mg} / \mathrm{L}$ and $0.5 \mathrm{mg} / \mathrm{L}$ of the free chlorine because the minimum concentration required by the $\mathrm{MH} 2.914 / 2011$ is $0.2 \mathrm{mg} / \mathrm{L}$ [22]. The temperatures selected were $15^{\circ} \mathrm{C}$ and $20^{\circ} \mathrm{C}$, for $0.2 \mathrm{mg} / \mathrm{L}$ and $0.5 \mathrm{mg} / \mathrm{L}$ of the free chlorine, except for the experiments with the BDF buffer, which were only performed at $20^{\circ} \mathrm{C}$. The volume used in the experiment was $10 \mathrm{~mL}$ to be able to observe a $4 \log _{10}$ decay $(100 \mu \mathrm{L}$ viral inoculums - $9 \times 10^{7} \mathrm{FFU}$ ), although the same experimental conditions were also performed with $40 \mathrm{~mL}$ $\left(400 \mu \mathrm{L}\right.$ viral inoculums $\left.-3.6 \times 10^{8} \mathrm{FFU}\right)$ (Table 4). All of the experiments were performed in duplicate.

Free chlorine decay in water samples All of the experiments that evaluated the free chlorine decay were performed with $50 \mathrm{~mL}$, because the technique (DPD method - HANNA Instruments (HI 95711)) used requires aliquots of $10 \mathrm{~mL}$ per analysis point.
In the glassware chlorine-free beakers, $50 \mathrm{~mL}$ of the LP, MQ and BDF buffer ( $\mathrm{pH} 6.9$ and 8.0) with $0.2 \mathrm{mg} / \mathrm{L}$ and $0.5 \mathrm{mg} / \mathrm{L}$ of the free chlorine were stirred at $20^{\circ} \mathrm{C}$, and the free chlorine concentration was determined at a minimum at the beginning (time $0 \mathrm{~s}$ ) and at the end of the disinfection time by the DPD method, using the HANNA Instruments (HI 95711).

Free chlorine decay in water samples with virus stock For this assay, the same procedure was performed as described in section 2.4.4.1; however, this time with the addition of $500 \mu \mathrm{L}$ of the purified virus stock.

Positive controls In the glassware chlorine-free beakers, $10 \mathrm{~mL}$ of the LP, MQ and BDF buffer (pH 6.9 and 8.0) with $100 \mu \mathrm{L}$ of the purified virus stock were stirred at $20^{\circ} \mathrm{C}$. Four-hundred microliter aliquots were taken at the selected time points $(0 \mathrm{~s}, 30 \mathrm{~min}$ and $60 \mathrm{~min})$, kept on ice until the last time points were taken and analyzed by fluorescence microscopy and qPCR for the presence of viruses and the viability tests.

Viral inactivation by free chlorine In the glassware chlorine-free beakers, $10 \mathrm{~mL}$ of the LP, MQ and BDF buffer ( $\mathrm{pH} 6.9$ and 8.0) with $100 \mu \mathrm{L}$ of the purified virus stock with $0.2 \mathrm{mg} / \mathrm{L}$ and $0.5 \mathrm{mg} / \mathrm{L}$ of the free chlorine were stirred at $15^{\circ} \mathrm{C}$ and $20^{\circ} \mathrm{C}$. Four-hundred microliter aliquots were taken, and the residual free chlorine was immediately quenched by placing the samples into collection tubes containing a sterile $10 \%$ sodium thiosulfate solution. The samples were kept on ice until the last time point was taken and analyzed by fluorescence microscopy and $\mathrm{qPCR}$ for the presence of viruses and the viability.

The same protocol was repeated using $40 \mathrm{~mL}$ of the water matrix and $400 \mu \mathrm{L}$ of the purified virus to certify that the results obtained using minor water volumes $(10 \mathrm{~mL})$ do not exhibit any significant difference when

Table 4 Experimental design for disinfection

\begin{tabular}{|c|c|c|c|c|}
\hline Water sample/Control $^{a}$ & $\begin{array}{l}\text { Volume used in the } \\
\text { experiment }(\mathrm{mL})\end{array}$ & $\mathrm{pH}$ & Temperature $\left({ }^{\circ} \mathrm{C}\right)$ & Chlorine concentration (mg/L) \\
\hline \multirow[t]{2}{*}{$L P$} & 10 & 6.9 & $15 / 20$ & 0.2 \\
\hline & & & & 0.5 \\
\hline$L P$ & 40 & 6.9 & 20 & 0.2 \\
\hline \multirow[t]{2}{*}{ MQ } & 10 & 6.5 & $15 / 20$ & 0.2 \\
\hline & & & & 0.5 \\
\hline MQ & 40 & 6.5 & 20 & 0.2 \\
\hline \multirow[t]{2}{*}{ BDF } & 10 & 8.0 & 20 & 0.2 \\
\hline & & & & 0.5 \\
\hline \multirow[t]{2}{*}{ BDF } & 10 & 6.9 & 20 & 0.2 \\
\hline & & & & 0.5 \\
\hline
\end{tabular}

a LP: Lagoa do Peri Water Treatment Plant; MQ: Morro dos Quadros Water Treatment Plant; BDF: Buffered demand free. Treatment applied to each sample, according to volume, $\mathrm{pH}$, temperature and chlorine concentration. 
compared with larger volumes, as used by some authors in the literature $[3,5,17]$.

\section{Evaluation of viral inactivation by cell culture methods} Cytotoxicity tests The cytotoxicity tests were performed to evaluate the potential toxicity caused by the LP and MQ samples in the HEK 293A cells to be used during the disinfection studies. The HEK 293A cell monolayers $\left(1.87 \times 10^{5}\right.$ cells/well) were propagated in 24-well plates (TPP, Switzerland) for $24 \mathrm{~h}$ at $37^{\circ} \mathrm{C}$ in $5 \% \mathrm{CO}_{2}$. The growth medium was discarded, and an inoculum of $100 \mu \mathrm{L} /$ well of the pure or diluted samples $(1: 2$, $1: 4,1: 8$, or $1: 16)$ was prepared in serum-free culture medium (DMEM 1X, 1\% PSA - $10 \mathrm{U} / \mathrm{mL}$ penicillin, $10 \mu \mathrm{g} / \mathrm{mL}$ streptomycin, $2 \mathrm{ng} / \mathrm{mL}$ amphotericin B) and adsorbed into the cells. After $1 \mathrm{~h}$ of incubation at $37^{\circ} \mathrm{C}$ in $5 \% \mathrm{CO}_{2}, 650 \mu \mathrm{L}$ of the maintenance medium (DMEM $1 \mathrm{X}$, containing $2 \%$ FBS, $1 \%$ HEPES, and 1\% PSA) was added. After $24 \mathrm{~h}$, the cell monolayers were observed under an inverted light microscope. These cells were fixed and stained with $0.1 \%$ crystal violet to establish a first non-cytotoxic dilution for use in further viral infectivity assays.

Cytotoxicity tests of the t-LP, t-MQ, n-LP and n-MQ samples were performed in the A549 cell monolayers $\left(2.5 \times 10^{5}\right.$ cells/well), as described for the HEK 293A cells, with the exception of the maintenance medium (DMEM $\uparrow$ G 1X, 2\% FBS and 1\% PSA), and the monolayers were monitored for 7 days, until the staining.

Fluorescence Microscopy (FM) The HEK 293A cells were grown to obtain confluent monolayers $\left(1.5 \times 10^{5}\right.$ cells/well) in a 48 -well plate for $24 \mathrm{~h}$ at $37^{\circ} \mathrm{C}$ in $5 \% \mathrm{CO}_{2}$. The growth medium was discarded, and $100 \mu \mathrm{L}$ of each water dilution with $1 \%$ PSA was inoculated in duplicate. The cells were incubated for $1 \mathrm{~h}$, and then $400 \mu \mathrm{L}$ of the maintenance medium was added. After $24 \mathrm{~h}$ p.i., the cells were then observed under an epifluorescence microscope with UV light (Olympus). The viral titer was determined by the following formula: (average green cells counted $x$ reciprocal dilution)/inoculum $(\mathrm{mL})$. The results are shown in Focus Forming Units per milliliter $(\mathrm{FFU} / \mathrm{mL})$. Figure $1 \mathrm{H}$ displays an example of the infected green fluorescent cells that were counted and considered to determine the viral titer.

\section{Evaluation of viral inactivation by molecular methods} Nucleic acid isolation and quantitative PCR (qPCR) The extraction of the viral nucleic acid was performed using a commercial QIAmp MinElute Virus Spin Kit (Qiagen, Valencia, CA, USA), according to the manufacturer's instructions. The nucleic acid was eluted in $60 \mu \mathrm{L}$ of the elution buffer and stored at $-80^{\circ} \mathrm{C}$ until use for the real-time PCR (quantitative PCR).
For the detection of rAdV, quantitative PCR was performed, as described by Hernroth et al. 2002 [55]. The reaction contained 1:10 dilutions of each sample and the TaqMan PCR master mix (Applied Biosystems, Foster City, CA), along with the primers and TaqMan probes at a volume of $25 \mu \mathrm{L}$. All of the amplifications were performed in the StepOne Plus ${ }^{\circ}$ Real-Time PCR System (Applied Biosystems). Each sample was analyzed in triplicate. For each plate, four serial dilutions of the standard were run in triplicate for each assay, and the genome copies (gc) were measured. Ultra-pure water was used as the non-template control for each assay.

\section{Kinetic modeling and statistical analysis}

The statistical analyses were performed using GraphPad Prism version 5.0 (USA). Student's t test was performed, and all significant differences are quoted for $\mathrm{P}<0.05$. The data were previously confirmed for a normal distribution fitting.

The chlorine decay constant $\left(k^{\prime}\right)$ for each experiment was calculated using Microsoft Excel 2007, according to the following equation:

$$
\mathrm{C}(\mathrm{t})=\mathrm{C}_{0} \exp \left(-k^{\prime} t\right)
$$

where $C(t)$ and $C_{0}$ is the concentration of the free residual chlorine $(\mathrm{mg} / \mathrm{L})$ at time $\mathrm{t}$ and at time 0 , respectively, and $k^{\prime}$ is the first-order decay rate constant $\left(\mathrm{min}^{-1}\right)$.

The values of the viral inactivation observed by fluorescence microscopy (FFU/mL) were subjected to the previously described Chick-Watson model to predict the contact time:

$$
\operatorname{Ln} N / N_{0}=-\mathrm{k} / \mathrm{k}^{\prime} \mathrm{n}\left(\mathrm{C}_{0}{ }^{\mathrm{n}}-\mathrm{C}_{\mathrm{t}}{ }^{\mathrm{n}}\right)
$$

where $L n N / N_{O}$ is the natural logarithm of the survival rate (concentration of viable virus at time $t$ divided by the concentration at time 0$), k$ is the inactivation constant rate and $n$ is the coefficient of dilution. The $K$ value of 0.0001 was adopted when the decay of the disinfectant was considered negligible [3], and the $n$ value was considered 1 [63].

The $\mathrm{Ct}$ values $(\mathrm{mg} / \mathrm{L} \times \mathrm{min})$ predicted for the viral inactivation were determined by multiplying the time $(\mathrm{min})$ and the concentration of free chlorine $\left(C_{t}^{n}\right)$ at each time interval that were calculated by the Chick-Watson model when an approximate $2 \log _{10}, 3 \log _{10}$, and $4 \log _{10}$ inactivation occurred.

Competing interests

The authors declare that they have no competing interests. 


\section{Authors' contributions}

MAN and CRMB designed the research. MAN carried out the collection of water samples and concentration of treated water samples, physicochemical parameters and fecal contamination analysis, reagents and glassware treatments, cytotoxicity tests, disinfection assays, microscopy fluorescence and $\mathrm{qPCR}$ assays. MEM and MAN carried out the kinetic modeling and statistical analysis.CDS performed the plaque assay. CRMB conceived of the study, and participated in its design and coordination and helped to draft the manuscript. All authors read and approved the final manuscript.

\section{Acknowledgments}

Financial support for this research was provided by National Counsel of Technological and Scientific Development (CNPq) and Coordenação de Aperfeiçoamento de Pessoal de Nível Superior (CAPES).

Received: 26 November 2014 Accepted: 3 February 2015

Published online: 22 February 2015

\section{References}

1. Bosch A, Guix S, Sano D, Pinto RM. New tools for the study and direct surveillance of viral pathogens in water. Curr Opin Biotechnol. 2008;19:295-301.

2. Sobsey MD, Fuji T, Hall RM. Inactivation of cell-associated and dispersed hepatitis A virus in water. J Am Water Works Assoc. 1991;83:64-7.

3. Thurston-Enriquez JA, Haas CN, Jacangelo J, Gerba CP. Chlorine inactivation of adenovirus type 40 and feline calicivirus. Appl Environ Microbiol. 2003;69:3979-85.

4. USEPA - United States Environmental Protection Agency. Guidance manual for compliance with the filtration and disinfection requirements for public water systems using surface water sources. Washington, DC: United States Environmental Protection Agency; 1991.

5. Kahler AM, Cromeans TL, Roberts JM, Hill VR. Effects of source water quality on chlorine inactivation of adenovirus, coxsackievirus, echovirus, and murine norovirus. Appl Environ Microbiol. 2010;76:5159-64.

6. Fong TT, Lipp EK. Enteric viruses of human and animals in aquatic environments: health risks, detection, and potential water quality assessment tools. Microbiol Mol Biol Rev. 2005;69:357-71.

7. King $A M Q$, Adams MJ, Carstens EB, Lefkowitz EJ. Virus taxonomy: classification and nomenclature of viruses. Ninth report of the internationa committee on taxonomy of viruses. San Diego: Elsevier, Academic Press; 2012.

8. USEPA - United States Environmental Protection Agency. Final contaminant candidate list 3 microbes: PCCL to CCL process. Washington, DC: United States Environmental Protection Agency; 2009.

9. Choi S, Jiang SC. Real-time PCR quantification of human adenoviruses in urban rivers indicates genome prevalence but low infectivity. Appl Environ Microbiol. 2005;71:7426-33.

10. Albinana-Gimenez N, Miagostovich MP, Calgua B, Huguet JM, Matia L, Girones R. Analysis of adenoviruses and polyomaviruses quantified by qPCR as indicators of water quality in source and drinking-water treatment plants. Water Res. 2009;43:2011-9.

11. Dong Y, Kim J, Lewis GD. Evaluation of methodology for detection of human adenoviruses in wastewater, drinking water, stream water and recreational waters. J Appl Microbiol. 2010;108:800-9.

12. Wyn-jones AP, Carducci A, Cook N, D'Agostino M, Divizia M, Fleischer J, et al. Surveillance of adenoviruses and noroviruses in European recreational waters. Water Res. 2011;45:1025-38.

13. Fongaro G, Nascimento MA, Viancelli A, Tonetta D, Petrucio MM, Barardi CRM. Surveillance of human viral contamination and physicochemical profiles in a surface water lagoon. Water Sci Technol. 2012;66:2682-7.

14. Garcia LAT, Viancelli A, Rigotto C, Pilotto MR, Esteves PA, Kunz A, et al. Surveillance of human and swine adenovirus, human norovirus and swine circovirus in water samples in Santa Catarina, Brazil. J Water Health. 2012:10:445-52

15. Ye XY, Ming X, Zhang YL, Xiao WQ, Huang XN, Cao YG, et al. Real-time PCR detection of enteric viruses in source water and treated drinking water in Wuhan, China. Curr Microbiol. 2012;65:244-53.

16. Page MA, Shisler JL, Mariñas BJ. Kinetics of adenovirus type 2 inactivation with free chlorine. Water Res. 2009:43:2916-26.
17. Cromeans TL, Kahler AM, Hill VR. Inactivation of adenoviruses, enteroviruses, and murine norovirus in water by free chlorine and monochloramine. Appl Environ Microbiol. 2010;76:1028-33.

18. Corrêa AA, Carratala A, Barardi CRM, Calvo M, Girones R, Bofill-Mas S. Comparative inactivation of murine norovirus, human adenovirus, and human JC polyomavirus by chlorine in seawater. Appl Environ Microbiol. 2012;78:6450-7.

19. Francy DS, Stelzer EA, Bushon RN, Brady AMG, Williston AG, Riddell KR, et al. Comparative effectiveness of membrane bioreactors, conventional secondary treatment, and chlorine and UV disinfection to remove microorganisms from municipal wastewaters. Water Res. 2012;46:4164-78.

20. Luo J, Deng ZL, Luo X, Tang N, Song WX, Chen J, et al. A protocol for rapid generation of recombinant adenoviruses using the AdEasy system. Nat Protoc. 2007;2:1236-47.

21. Graham FL, Smiley J, Russell WC, Nairn R. Characteristics of a human cell line transformed by DNA from human adenovirus type 5. J Gen Virol. 1977;36:59-72.

22. ANVISA. Agência Nacional de Vigilância Sanitária: Ordinance $n^{\circ}$ 2914/MH of December 12. Brasília: Ministry of Health; 2011.

23. Fontes MLS, Tonetta D, Dalpaz L, Antônio RV, Petrucio MM. Dynamics of planktonic prokaryotes and dissolved carbon in a subtropical coastal lake. Front Microbiol. 2013;4:71-9.

24. Chigor VN, Sibanda T, Okoh Al. Assessment of the risks for human health of adenoviruses, hepatitis a virus, rotaviruses and enteroviruses in the buffalo river and three source water dams in the eastern cape. Food Environ Virol. 2014;6:87-98.

25. Fewtrell L, Kay D, Watkins J, Davies C, Francis C. The microbiology of urban UK floodwaters and a quantitative microbial risk assessment of flooding and gastrointestinal illness. J Flood Risk Manage. 2011;4:77-87.

26. Girones R, Ferrús MA, Alonso JL, Rodriguez-Manzano J, Calgua B, Corrêa AA, et al. Molecular detection of pathogens in water - the pros and cons of molecular techniques. Water Res. 2010;44:4325-39.

27. Kundu A, McBride G, Wuertz S. Adenovirus-associated health risks for recreational activities in a multi-use coastal watershed based on site-specific quantitative microbial risk assessment. Water Res. 2013;47:6309-25.

28. Zhang CM, Wang XC. Distribution of enteric pathogens in wastewater secondary effluent and safety analysis for urban water reuse. Hum Ecol Risk Assess. 2014:20:797-806.

29. Prütz WA. Reactions of hypochlorous acid with biological substrates Are activated catalytically by tertiary amines. Arch Biochem Biophys. 1998:357:265-73.

30. Page MA, Shisler JL, Marinãs BJ. Mechanistic aspects of adenovirus serotype 2 inactivation with free chlorine. Appl Environ Microbiol. 2010;76:2946-54.

31. Cromeans TL, Lu X, Erdman DD, Humphrey CD, Hill VR. Development of a plaque assay for adenoviruses 40 and 41. J Virol Methods. 2008;151:140-5.

32. Mazzola PG, Ishii M, Chau E, Cholewa O, Penna TC. Stability of Green Fluorescent Protein (GFP) in chlorine solutions of varying $\mathrm{pH}$. Biotechnol Progr. 2006;22:1702-7.

33. Webb JS, Barratt SR, Sabev H, Nixon M, Eastwood IM, Greenhalgh M, et al. Green fluorescent protein as a novel indicator of antimicrobial susceptibility in Aureobasidium pullulans. Appl EnViron Microbiol. 2001;67:5614-20.

34. Casey WM, Nguyen NT. Use of the green fluorescent protein to rapidly assess viability of Escherichia coli in preserved solutions. PDA J Pharm Sci Tech. 1995:50:352-5.

35. AWWA - American Water Works Association. Water chlorination/chloramination practices and principles, Manual of water supply practices - M20. Denver, Colorado: American Water Works Association; 2006.

36. Krauskopf BK. Introduction to geochemistry. New York: McGraw- Hill; 1983.

37. Pettry DE, Switzer RE. Heavy metal concentration in selected soils and parent materials in Mississippi, Bulletin 998. MSU: Meridian; 1993.

38. Andrade LN, Leite MGP, Bacellar LAP. Influence of the geology in the chemical signature of water and soils from the Itacolomi State Park, Minas Gerais. R Esc Minas. 2009:62:147-54.

39. Howland RJ, Tappin AD, Uncles RJ, Plummer DH, Bloomer NJ. Distributions and seasonal variability of $\mathrm{pH}$ and alkalinity in the Tweed Estuary, UK. Sci Total Environ. 2000;251-252:125-38.

40. Morris AW, Mantoura RFC, Bale AJ, Howland RJM. Very low salinity regions of estuaries: important sites for chemical and biological reactions. Nature. 1978;274:678-80.

41. Wang X, Cai Q, Ye L, Qu X. Evaluation of spatial and temporal variation in stream water quality by multivariate statistical techniques: A case study of the Xiangxi River basin, China. Quatern Int. 2012;282:137-44. 
42. Belevantsev VI, Ryzhikh AP, Smolyakov BS. Diurnal and vertical variability of $\mathrm{pH},\left[\mathrm{O}_{2}\right]$, and $E_{\mathrm{h}}$ in the Novosibirsk water reservoir. Russ Geol Geophys. 2008;49:673-81.

43. Palma P, Ledo L, Soares S, Barbosa IR, Alvarenga P. Spatial and temporal variability of the water and sediments quality in the Alqueva reservoir (Guadiana Basin; southern Portugal). Sci Total Environ. 2014:470-471:780-90.

44. Manahan SE. Environmental chemistry. 9th ed. Boca Raton, Florida: Taylor \& Francis Group; 2010.

45. March JG, Gual M, Ramonell J. A kinetic model for chlorine consumption in greywater. Desalination. 2005;181:267-73.

46. Winward GP, Avery LM, Stephenson T, Jefferson B. Chlorine disinfection of grey water for reuse: effect of organics and particles. Water Res. 2008:42:483-91.

47. Daskalakis V, Charalambous F, Panagiotou F, Nearchou I. Effects of surface-active organic matter on carbon dioxide nucleation in atmospheric wet aerosols: a molecular dynamics study. Phys Chem Chem Phys. 2014;16:23723-34.

48. Winter J, Ilbert M, Graf PCF, Ozcelick D, Jakob U. Bleach activates redox-regulated chaperone by oxidative protein unfolding. Cell. 2008;135:691-701.

49. Pattison DI, Davies MJ. Absolute rate constants for the reaction of hypochlorous acid with protein side chains and peptide bonds. Chem Res Toxicol. 2001;14:1453-64.

50. Ma JF, Straub TM, Pepper IL, Gerba CP. Cell culture and PCR determination of poliovirus inactivation by disinfectants. Appl Environ Microbiol. 1994;60:4203-6.

51. Kitajima M, Tohya $Y$, Matsubara K, Haramoto E, Utagawa E, Katayama $\mathrm{H}$. Chlorine inactivation of human norovirus, murine norovirus and poliovirus in drinking water. Lett Appl Microbiol. 2010;51:119-21.

52. Lim MY, Kim JM, Ko G. Disinfection kinetics of murine norovirus using chlorine and chlorine dioxide. Water Res. 2010;44:3243-51.

53. Shin GA, Sobsey MD. Inactivation of norovirus by chlorine disinfection of water. Water Res. 2008;42:4562-8.

54. Xue B, Jin M, Yang D, Guo X, Chen Z, Shen Z, et al. Effects of chlorine and chlorine dioxide on human rotavirus infectivity and genome stability. Water Res. 2013;47:3329-38.

55. Hernroth BE, Conden-Hansson AC, Rehnstam-Holm AS, Girones R, Allard AK. Environmental factors influencing human viral pathogens and their potential indicator organisms in the blue mussel, Mytilus edulis: the first Scandinavian report. Appl Environ Microbiol. 2002;68:4523-33.

56. Helmi K, Skraber S, Gantzer C, Willame R, Hoffmann L, Cauchie HM Interactions of Cryptosporidium parvum, Giardia lamblia, vaccinal poliovirus type 1, and bacteriophages $\varphi 174$ and MS2 with a drinking water biofilm and a wastewater biofilm. Appl Environ Microbiol. 2008;74:2079-88.

57. Szewzyk U, Szewzyk R, Manz W, Schleifer KH. Microbiological safety of drinking water. Annu Rev Microbiol. 2000;54:81-127.

58. Daniel LA. Rede cooperativa de pesquisas: Métodos alternativos de desinfecção da água, Prosab. Rio de Janeiro: ABES; 2001.

59. Calgua B, Fumian T, Rusiñol M, Rodriguez-Manzano J, Mbayed VA, Bofill-Mas $S$, et al. Detection and quantification of classic and emerging viruses by skimmed-milk flocculation and PCR in river water from two geographical areas. Water Res. 2013;47:2797-810.

60. Golterman HL, Clymo RS, Ohnstad MAM. Methods for physical and chemical analysis of freshwater. Oxford: Blackwell Scientific Publications; 1978.

61. Mackereth FJH, Heron J, Talling JF. Water Analysis: some revised methods for limnologists, Freshwater biological association, scientific publication. Kendal: Titus Wilson \& Sons Ltda; 1978.

62. Koroleff F. Determination of nutrients. In: Grasshoff K, editor. Methods of Sea water analysis. 1st ed. Weinhein: Verlag Chemie; 1976. p. 117-81.

63. MWH - Montgomery Watson Harza. Water treatment: principles and design. Hoboken, New Jersey: John Wiley \& Sons; 2005.

\section{Submit your next manuscript to BioMed Central and take full advantage of:}

- Convenient online submission

- Thorough peer review

- No space constraints or color figure charges

- Immediate publication on acceptance

- Inclusion in PubMed, CAS, Scopus and Google Scholar

- Research which is freely available for redistribution

Submit your manuscript at www.biomedcentral.com/submit 